\section{A POLICY FIASCO: THE INSTITUTIONAL (NON-)REFORM OF CZECH PUBLIC EMPLOYMENT SERVICES IN 2011}

Miriam Kotrusová, Klára Výborná ${ }^{1}$

Charles University in Prague

Abstract: The article deals with an institutional reform of public employment services implemented in the Czech Republic in 2011. By merging social benefits administration with employment services into the newly established Labour office of the Czech Republic, the right-wing government attempted to reduce the staffing and administrative costs of these services and to improve the governance of local labour offices. Using the theoretical concept of "policy fiasco" and taking an interpretive perspective thereon, we analyse these organisational changes in the functioning of public employment services in the Czech Republic. Our data consist of interviews with experts on labour market policy in the Czech Republic and two focus groups with employees of labour offices who had participated in the reform process. We conclude that the institutional reform of public employment services in the Czech Republic in 2011 can be referred to as a policy fiasco in the sense of the theoretical concept used in the work of Bovens and t'Hart (1998).

Keywords: public employment services, Czech Republic, institutional reform, policy fiasco, interpretive paradigm

MIRIAM KOTRUSOVÁ - Faculty of Social Sciences, Charles University in Prague • miriam.kotrusova@fsv.cuni.cz

KLÁRA VÝBORNÁ - Faculty of Social Sciences, Charles University in Prague • klaravyborna@gmail.com
1 The work on this article has been supported by the Charles University Grant Agency (project No 878413) and by the Charles University Specific Academic Research Projects Competition (project No. 260232).
Central European Journal of Public Policy

Vol. 9 - № 1 - May 2015 - pp 148-169

ISSN $1802-4866$

(c) 2015 Miriam Kotrusová, Klára Výborná

Licensed under Creative Commons Attribution 3.0

\section{INTRODUCTION}

In the year 2011, the Czech Republic implemented a series of institutional changes to the management and operations of public employment services. As a result, a new Labour Office of the Czech Republic was established, an independent government body with its own responsibilities. The main goal of these changes, as communicated explicitly to the public, was to reduce the staffing and operational costs of the Labour Office by merging the agenda of all welfare benefits in one institution. The reform further introduced a new management level in the organizational structure of employment services, namely the regional level. Local (district) offices were no longer managed directly by central government, and instead, the regional offices were instituted as their direct superior body.

From the beginning, the implementation of the institutional reform of public employment services by the right-wing coalition government of the Civic Democratic Party, the TOP09 and the Public Affairs was accompanied by a number of non-consensual and non-transparent decisions (e.g., a criminal prosecution with regard to an information system for labour offices) (Vlková \& Petrášová, 2013) or failures in the implementation of certain measures that are normally used in other countries' welfare systems (e.g., electronic cards for the collection of welfare benefits (Vláda ČR, 2013). Following the snap election of 2013, the new centre-left government coalition of the Social Democrats, the ANO and the Christian Democrats initiated a project to assess the reform's overall effects and improve the management and operational procedures of Czech employment services.

This article seeks to determine whether or not the 2011 institutional reform of Czech public employment services can be referred to as a specific type of major policy failure, namely a policy fiasco. According to Bovens and t'Hart (1998) a fiasco "only refers to situations of: a) significant social damage, that b) are highly politicized". (p. 15) As we are going to demonstrate in this article, both these conditions were met in the case of the organizational changes to Czech employment services analysed here. In the following text, we will first describe the initial state of the organizational structure of public employment services prior to the reform of 2011. Then we will discuss the main problems 
faced by Czech employment services at that time. We will explain the main goals, course and effects of the 2011 institutional reform of employment services. Our effort to identify the causes of the policy fiasco will be based on an interpretive approach to subjective evaluations of the organizational changes implemented that were expressed by experts and members of labour offices staff.

\section{POLICY FAILURE AND POLICY FIASCO}

Policy failure is one of the established theoretical concepts of political science and public policy (e.g., Ingram \& Mann, 1980; Fiala \& Schubert, 2000; Weimer \& Vining, 2005; Birkland, 2005; Veselý \& Nekola, 2007; Araral, Fritzen Howlett, \& $\mathrm{Wu}, 2012)$. In spite of the long-term record of policy failure studies, a relatively complicated procedure is required in order to identify a policy failure and determine the degree of its importance. It may be difficult to interpret an event as a failure because there are often competing interpretations of policy choices and the different variables that might support this effort tend to be vague and ambiguous. Certain symptoms of failure may be ignored by some actors and exaggerated by others (McConnell, 2013).

There are two basic paradigms in policy failure studies. First, the rationalist approach to policy failure draws a clear line between evidence and evaluation. Its underlying assumption is that every policy has clearly defined goals and its effects are measured by objective indicators. Exact empirical evidence enables us to determine which policies are functional and which ones are fail ing (Veselý \& Nekola, 2007). The second paradigm is referred to as interpretivism. Here, policy effects are determined on the basis of people's evaluations, rather than evidence gathered in the form of quantitative indicators. Such evaluations are seen as inherently subjective and inseparable from different actors policy claims, particular interests and perceived needs. The same issue matter can be interpreted in highly contrasting ways, and there is often no method to produce an ultimate, unambiguous evaluation. Which one of the compet ing interpretations prevails depends on the clashes waged by different actors and on the compromises achieved by them (Hoppe, 1999; Colebatch \& Hoppe \& Noordegraaf, 2010). In order to determine whether a given situation is a policy success or a policy failure, the interpretive paradigm recommends more-orless independent, verifiable assessment of specific policy aspects (policy goals versus outcomes, positive and negative effects on the target group, or elimination of the defined problem). Nevertheless, the ambition of interpretivist analysis is not to reveal the definite sources and contents of a policy failure, but merely to draw a picture of the claims made by different actors (Hoppe, 1999 2011; Yanow, 2006)

In one of his typologies of policy failures, McConnell (2010) distinguishes between different policy failures in the levels of government policy, programme and implementation process. Howlett (2012) argues that a number of existing studies neglect to define the types and different aspects of policy failure that they analyse. This leads to flaws in the generalization of findings, conceptual ambiguities, and disruptions in the cumulative process of theory building. While every effort to measure the importance of a policy failure is rather an art project than science, McConnell (2013) distinguishes between three degrees of importance: low-level failure, moderate-level failure and highlevel failure. Low-level failures include minor drawbacks and small deviations from the planned course of policy implementation. Moderate-level failures refer to policies that are failing in some of their aspects or from the perspective of some actors, while their overall implementation is relatively satisfactory. In other words, in the presence of moderate-level failures, the given policy still has identifiable positive effects or achievements that justify continued implementation. High-level failures are widespread and sizable; even so, policy makers may choose to tolerate or eliminate them in order to prevent the policy from being recognized as a failure and avoid being held politically accountable for it.

When studying major failures in the policy process, policy scholars do not always refer to them as policy fiascos; there is a number of synonyms such as policy accidents, policy disasters, policy catastrophes and policy anomalies. (Howlett, 2012). The term policy fiasco was coined by Bovens and t'Hart (1998) who took an interpretive approach to studying the phenomenon. In their definition, a policy fiasco is "a negative event that is perceived by a socially and politically significant group of people in the community to be at least partially caused by avoidable and blameworthy failures of public policymakers" (Bovens \& t'Hart, 1998, p. 15). It is both a social construction and a reflection of objective difficulties in a policy area. Designating an event of acute failure a policy fiasco is a rhetorical, political, interpretive and evaluative act (ibid).

Before an event is defined as a policy failure, it is recommended by Bovens and t'Hart (1998) to address four layers of questions. The first question is: What happened? The goal is to identify the kind of events that are perceived as failures, and to assess "how bad" those events are regarded, "by whom and according to what standards" (Bovens \& t'Hart, 1998, p. 11). Questions of the second type are asked to identify specific agents behind the policy fiasco, i.e. ones that can be made accountable for the negative events at stake. A necessary condition of a policy fiasco is that such events are believed to be caused 
by people's actions. The third layer of questions in the process of identifying policy fiascos helps us explain the causes and rationales that prompted the negative events at stake or, in other words, to account for the policy process that preceded the fiasco. Here, one studies "the composition of the policymaking arena, the allocation of political or agency attention, the gathering and processing of information, the recognition and resolution of value conflicts, the distribution of power among key stakeholders in the arena, the decision rules guiding the selection of actions, the organization of implementation, and the degree of political control over the actions of lower-level operatives" (Bovens \& t'Hart, 1998, p. 13). Finally, using questions of the fourth type, one seeks to assess whether or not the negative events at stake were avoidable. This requires studying "the claims of the accusers, as well as at the excuses and justifications brought forward by the agents and their supporters", all of which "require an assessment against a certain set of norms and values." (Bovens \& t'Hart, 1998 p. 13-14) Events that are found by the accusers as predictable and thus avoidable are especially prone to criticism and tend to imply clear political consequences. (Ibid.)

As noted by Bovens and t'Hart (1998), "those who want to study the dynamic of policy fiascoes face a semantic and normative minefield". (p. 14) For that reason, the authors are highly specific with regard to the basic principles that underlie their analysis. In short, they postulate inevitable subjectivity (impossibility to identify objective indicators and tools to evaluate controversial policy events), normative pluralism (different actors have different norms and criteria of evaluation that are determined by their professional affiliations), an explicit meta-theoretical orientation (the interpretive paradigm), and a focus on broader social contexts of the events analysed.

Our approach to evaluation of the institutional reform of public employment services in 2011 is based on the interpretive perspective. We assume that there are no precise definitions of policy success and policy failure because the underlying assessments are strongly subjective and motivated by particular in terests. In other words, instead of an explicit definition of the term, we only have an implicit one; policy failures and the contexts in which they are debated are never strictly delimited (Birkland, 2005). Moreover, we believe that in the implementation process, street-level bureaucrats become the key policy makers, which leads to a democratic and accountability deficit (Evans, 2010). The more-or-less justified beliefs of the street-level bureaucrats that the changes implemented were essentially wrong may themselves have contributed to the fundamental failure of the policy that we refer to as a policy fiasco.

\section{METHODS AND DATA}

In order to determine whether or not the institutional reform of employment services in the Czech Republic was a specific type of policy failure, namely a policy fiasco, we analysed a number of primary and secondary sources. Our secondary sources consisted of existing analytical reports on Czech employment services, the ways they operate and the major problems they face; proposals and recommendations to reform those services, including legislative bills; and Práce a sociální politika, a print and online journal of the Ministry of Labour and Social Affairs. Using the latter source, we sought to identify the publicly declared goals of the 2011 reform. We examined all public statements of Minister of Labour and Social Affairs Jaromír Drábek with regard to the institutional reform of labour offices (its goals, course and effects) and, for the purposes of our analysis, we treated them as official statements of the Ministry. We analysed the full text of the journal's volumes 2011 and 2012: in early 2011, the reform's planning stage and related legislative activities culminated, and in October 2012, Minister Drábek resigned after criminal proceedings were initiated and his Deputy Minister was arrested on charges of bid rigging in a public tender for a new information system for labour offices (Nohl, Novák \& Šídlová, 2012).

An expert survey and focus groups were conducted to collect primary data on evaluations of the institutional reform of employment services. By means of semi-structured "systemizing expert interviews", the experts were invited to share some of their exclusive and specific knowledge and experiences (Flick, 2009; Bogner, Littig \& Menz, 2009). Purposeful sampling (Reichel, 2009) was applied to recruit six experts with different professional affiliations and specialized on employment policy and employment services in the Czech Republic (see Table 1). Our sampling procedure was driven by the effort to identify the views of all relevant stakeholders that had been involved in preparing the new law (Strategy Unit of the Ministry of Labour and Social Affairs, Analytical Units of the Czech-Moravian Confederation of Trade Unions, of the Confederation of Industry of the Czech Republic, and of the Union of Czech and Moravian Production Co-operatives as employer representatives), and employment policy researchers of the National Training Fund. In the course of data analysis, we conducted semi-structured interviews with two additional experts that we selected purposefully to gain insight into the views of people directly involved in the implementation of the reform (Respondents 7 and 8).

Our data collection was based on an interview scenario, which was communicated to our partners prior to their interview date to give them time for contemplating their answers. It covered a relatively wide range of topics: opin- 
ions about the initial state prior to the reform of 2011, as well as the reform's goals, content, process and effects. The interview topics were formulated in a general fashion to avoid suggestive questions and make sure our partners formulated their own perspectives.

Table 1 List of respondents and their professional affiliation

\begin{tabular}{ll}
\hline $\begin{array}{l}\text { Respondent } \\
\#\end{array}$ & Professional affiliation \\
\hline 1 & Labour Office of the Czech Republic, General Directorate, top manager \\
\hline 2 & $\begin{array}{l}\text { Ministry of Labour and Social Affairs, middle manager responsible for } \\
\text { labour market strategies and analyses }\end{array}$ \\
\hline 3 & Czech-Moravian Confederation of Trade Unions, economic expert \\
\hline 4 & $\begin{array}{l}\text { Confederation of Industry of the Czech Republic, top manager responsible } \\
\text { for employer relations }\end{array}$ \\
\hline 6 & National Training Fund, consultant in the Employment Unit \\
\hline 7 & Union of Czech and Moravian Production Co-operatives, top manager \\
\hline 8 & $\begin{array}{l}\text { Ministry of Labour and Social Affairs, top manager responsible for } \\
\text { implementation of the reform }\end{array}$ \\
\hline
\end{tabular}

In the autumn of 2014, additional primary data was collected by means of two focus groups (Kitzinger, 1995; Barbour, 2008) with civil servants who worked at local and regional employment offices and had directly experienced the reform's implementation process. One focus group consisted of street-level bureaucrats (a total of 12 employment counsellors and brokers) and the other one of employees of the Department of Labour Market Analysis (a total of 13 persons). The civil servants were invited to discuss the same issues as the experts interviewed.

Most expert interviews and both focus groups were tape-recorded, and their verbatim transcriptions were analysed. We employed the method of thematic analysis that aims to identify, analyse and discern topics in textual data (Boyatzis, 1998; Braun \& Clarke, 2006). The term topic refers to certain patterns that reveal something interesting and relevant to the research problem. A topic must occur repeatedly, at least in several cases (interviews), and should be easily distinguishable from other topics (King \& Horrocks, 2010).

\section{PUBLIC EMPLOYMENT SERVICES BEFORE}

\section{THE INSTITUTIONAL REFORM IN 2011}

Public employment services in the Czech Republic were a greenfield project of the post-communist transformation. The new labour offices modelled the practices of employment services known of democratic countries. There was little continuity with the former regime, in which municipal and district offices were responsible for centralized allocation of workforce with required qualifications to open job positions. In the early 1990s, Czech public administration successfully introduced state-of-the-art employment services which complied with the standards then applied in advanced European countries and provided relatively effective solutions to existing unemployment (cf. Orenstein, 1994; Boeri \& Burda, 1996; Horálek, 2000; Kalužná, 2008). In terms of the scope and degree of their activities, early 1990s public employment services in the Czech Republic were more developed than in other Central and Eastern European countries (Gitter \& Scheuer, 1998).

In the early 1990s, public employment services in the Czech Republic were institutionalized at two levels. The level of management and guidance consisted of the Employment Services Administration, a part of the federal, later national Ministry of Labour and Social Affairs. At the level of operations, there were 77 district labour offices, each having an independent legal personality. Besides some undeniable advantages, the two-level institutional structure also had two marked disadvantages. First, the level of management and guidance was overwhelmed with operational and funding issues with respect to the district labour offices. Second, it was seen as inadequate for the Employment Services Administration, with its direct responsibility for the management and guidance of district labour offices, to remain a part of the Ministry, yet several attempts to divorce the two institutions were unsuccessful. (Dosavadní návrhy, 2007)

In spite of highly centralized funding, there was a strong trend of decentralization of employment services in the Czech Republic before the institutional reform of 2011 (Kalužná, 2008). The institutional decentralization came with marked advantages, mainly in the implementation of active employment policies to facilitate the matching of local labour market supply with demand. In a comprehensive volume on the issues of labour market and employment policy, leading Czech experts argued there was an inadequately high level of variability in the organizational framework in which the main operations of labour offices in the Czech Republic took place (Sirovátka, 2008). Some experts talked about government failure, arguing that such a degree of decentralization and fragmentation was never intended by the government (Sirovátka, Winkler, 
2011). At the same time, this resulted in high levels of flexibility in the implementation of active employment policies at the local level, as acknowledged by an OECD ranking (OECD, 2009).

In the wake of the economic and social transformation, public employment services were able fulfil their role adequately, also thanks to low levels of unemployment. Over time, though, their reputation faded; a large part of general public limited their expectations of them to mere provision of unemployment benefits; and most employers identified them with the threat of site inspections and found it rather inconceivable to establish any meaningful cooperation with them (Kotíková et al., 2000). These trends can be attributed to insufficient coordination by the Ministry of Labour and Social Affairs, and to understaffing and a lack of further education programmes at local labour offices (Vylítová et al., 2000; Kotíková et al.; 2000, Sirovátka et al., 2003).

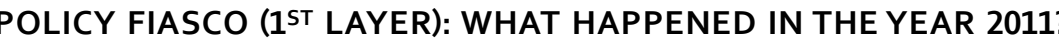

Adopted in February 2011, the new Act No. 73/2011, on the Labour Office of the Czech Republic, brought about important changes in the organizational struc ture of public employment services. Two months later, in April 2011, the Labour Office was established as an independent body with nationwide competence and three management levels. At the central level, the Labour Office is directed by the General Directorate. 14 regional bureaus were added between the existing central and local levels.

In the planning and legislative stage of the institutional reform of public employment services, the main goal of the reform was formulated as a reduction of approximately $10 \%$ in operational expenditure falling under the Ministry of Labour and Social Affairs (Návrh poslanců, 2010). The goal was also in line with the right-wing government's policy statement (Programové prohlášení vlády ČR, 2010). In order to achieve the savings as early as in 2011, the government planned raising the efficiency of the employment policy by transferring certain agendas and responsibilities of district labour offices to the regional level (Návrh poslanců, 2010). These agendas included legal, auditing, property management, $\mathrm{HR}$, and business administration operations; more over, a new information system was implemented. The Ministry of Labour and Social Affairs estimated to reduce operational cost by CZK 200 million in the first year following the introduction of the new organisational arrangements (MoLSA, undated)

This was followed in January 2012 by a merger of the social benefit agendas of former labour offices and municipalities into the newly established La- bour Office of the Czech Republic, which was also expected to result in savings. On top of their existing sizable agenda of welfare benefits, labour offices were newly made responsible for social assistance benefits, benefits for people with disabilities, social care benefits and foster care allowances (Integrovaný portál MPSV, 2014). "The goal is to have a one-stop-shop so that people are no longer forced to travel between government offices, submitting different applications to different bodies. We also aim at savings in operational expenditure of the state." (Slovo ministra, 2011, p. 1) An explanatory statement to Act No. 73/2011 gives a more detailed account of the goals of the new law, namely to separate and enhance the strategic, programming and legislative agendas of the employment policy, on one hand, and employment policy implementation, on the other hand; to transfer the responsibility for employment policy implementation to the Labour Office of the Czech Republic as a specialized body of government administration; and to strengthen the role of regional labour offices and make them the principal agents of employment policy implementation in the regions (Návrh poslanců, 2010)

\section{POLICY FIASCO (2ND LAYER): WHO WERE THE PRINCIPAL AGENTS?}

The institutional reform was pursued (and eventually pushed through in the Chamber of Deputies) exclusively by the government coalition and the political leadership of the Ministry of Labour and Social Affairs. Politically and professionally, the following should be held accountable for the different mistakes in the planning and implementation of the institutional reform of employment services: political leadership of the ministry at that time, Minister Drábek and Deputy Minister Šiška. "We hit the bottom around the time of Drábek's resignation..." (FG1). The installation of the new Labour Office and institutional structure of employment services was largely promoted by the political leadership of TOP09 (one of the coalition parties responsible for MoLSA) and all coalition MPs (Respondent 7). The main reason for such political pressure to adopt the new law was the length of the political cycle: "everyone knew that if this wasn't done in the first half of the parliamentary term, it would not happen" (Respondent 7). There were also significant managerial failures at the level of the Ministry. MoLSA staff was unable to respond to two concurrent processes, (1) the formation and stabilization of the new Labour Office and (2) the new agenda of welfare benefits with its new and then dysfunctional information system. Middle and senior managers at the MoLSA faced great stress and demotivation during that period (Respondent 7). 


\section{POLICY FIASCO (3RD LAYER): WHAT ARE THE} REASONS OF THE POLICY FIASCO?

\section{Main goal not defined in accordance with perceived needs}

The explicit primary goal of the organizational changes, i.e. to reduce government expenditure by CZK 175 million, was in contradiction to the nature of the problems employment services were facing at the height of the economic crisis. President Klaus even argued the savings from labour office reorganization were "fictitious" (Stanovisko prezidenta, 2011). Other statements made by Minister Drábek sought to mitigate public concern by arguing that the new law would not effectively abolish or restrict labour offices' agendas and a dense network of contact points would be preserved (Slovo ministra, 2011).

The experts interviewed who had been involved in the legislative stage of the reform stated that the reform's main goal was to streamline management processes in the different labour offices by implementing a new management structure. Before the reform, the organisational structure of the Labour Office differed from other government agencies (e.g., trade authorities or the Czech Social Security Administration - CSSA) that had been reformed as early as in 2004 (Respondent 7). The present reform aimed to merge the 77 local labour offices into a single agency and to replicate CSSA's management structure. (Respondent 8) This goal can be seen as adequate to the then existing state of the management mechanism, which had been criticized by a number of studies (e.g., Vylítová et al., 2000; Kotíková et al., 2000, Sirovátka et al., 2003, Dosavadní návrhy, 2007, Sirovátka \& Winkler, 2011). However, it was not presented by political leadership as the main goal of the employment services reform in 2011 financial savings were the explicit main goal.

In addition to streamlining the management and coordination of labour offices, it was necessary, above all, to increase the effectiveness of employment services' contact with clients (both job seekers and employers). (Kotíková et al., 2000, Vylítová et al. 2000, Dosavadní návrhy, 2007) “... the office was designed in a good way, but over time, it lost the image of modern employment services. This was obvious to us all." (FG1) The reform should have rather attempted to "standardize procedures, make a uniform environment; instead of layoffs, savings could have been achieved through standardization of supporting and operational procedures. Standard procedures might yield savings because the different offices wouldn't make isolated mistakes and waste time looking for the right solutions." (Respondent 1) According to the experts, the reform should have focused as well on strengthening the active employment policy in terms of funding and portfolio of policy measures. "The programmes of active employ- ment policy that are defined by the law should be made more flexible. They are outdated. There should be a larger portfolio of measures, with many more options. A variety of options is available in Austria, Germany etc. - they focus on short-term employment as well." (Respondent 5)

\section{Declared versus covert objectives}

Failure to attain defined goals, as one of the reasons of policy fiascos, may be caused by several things: implementation deficit (see below points 3 on inadequate planning of the reform and 5 on implementation failure), ill-defined and/ or covert goals. Politicians and public officials are sometimes reluctant to declare their true intentions in order to avoid critique by the opposition (Castles, 2004). The experts interviewed and the focus group participants often said they believed the institutional changes were driven not only by the primary goals but also by other, publicly undeclared goals. "The policymakers concealed the true character of the reform and the intention behind it ... and they used austerity arguments to conceal their actual goals." (Respondent 1) In their opinion, there was a "conspiracy to effectively abolish labour offices" (Respondent 2) or "cripple their operations" (Respondent 5). All agreed that the actual goals of the organizational changes were different than the ones declared officially. "The actual goal was ... to destroy the active employment policy ... and the goal was to have an office that provides basic information and a basic set of benefits; nothing more, nothing less." (Respondent 1) Private providers were supposed to replace labour offices in their primary mission, namely employment brokering, counselling and active labour market policy implementation. Effective from January 2012, the so-called shared brokering was introduced by an amendment to Act No. 435/2004 Coll., on employment. The Employment Office was allowed to pay to a private employment agency a grant of CZK 5000 for every client transferred under its responsibility (Article 119a). And the agency was eligible for additional grants of CZK 1250 for each successful placement with a permanent employment contract, and CZK 500 if the client retains for at least six months the job position that had been brokered. However, shared brokering was never implemented in practice. "At one point it appeared to me as purposeful fragmentation of the Labour Office" (FG2). "Yet the entire course of events seemed to substantiate the rumours that different agendas would be privatized, that certain employment agencies were prepared to acquire those agendas. But those were just sneaking suspicions." (FG1) 


\section{Inadequate planning of the reform}

The experts interviewed and the focus group participants agreed that "the reform that was implemented was not supported by any underlying analysis, any assessment of the situation, any identification of strengths and weaknesses, of things within that are outdated and things outside that had changed, to see what actually needs to be changed." (Respondent 1) Thus, the reform was "absolutely unprepared and built on wrong intentions ... it was actually a step back." (Respondent 5) However, the Ministry argued with a body of expert studies and recommendations as to the necessity of changing the employment services' management processes. (MoLSA, undated)

The actual process of planning, debating and implementing the institutional reform of employment services was very swift and unusual. The new Labour Office Act was tabled in the Chamber of Deputies only three months after the initial legislative intent was notified. Moreover, two parallel legislative processes went on. While the MoLSA was still gathering stakeholder comments on its proposal, the same text was tabled in the Chamber of Deputies by a group of coalition MPs (Respondent 7). The bill was met with serious criticism among the legislators, and top MoLSA officials promised to reconcile their comments in a subsequent amendment of the Act on the Labour Office of the Czech Republic. However, it failed to prepare the amendment because it was preoccupied with crippling failures in the information system for welfare provision. (Respondent 8)

"I generally think the reform was ill-prepared both by the General Directorate and by the Ministry. They should have at least postponed it till much later." (FG1) According to one of the experts who had been involved in the legislative stage, the political goals of the reform were not clear from the beginning. The original goal was to build a single government agency with regional branches. While working on that goal, the experts were given an additional task by the Ministry's political leadership, namely to merge welfare benefit agendas into the new Labour Office. The expert sees a fatal flaw in the fact that these two reform goals were addressed by a single proposal within an extremely short time frame that did not allow preparing a series of related laws and implementing the reform in practice. The new Labour Office did not have enough time to settle down and already was it faced with the new agenda of welfare benefits. (Respondent 7)

\section{Absence of consensus between stakeholders}

The main stakeholders failed to reach any basic consensus on the form of the new law; indeed, there was no effort to that end. "The way the draft Labour Office Law was consulted is, in my opinion, an unacceptable case of government arrogance and an apparent attempt by the government to destroy what's left of correctness in dealing with social partners." (Respondent 3) The government did not reconcile social partners' critical comments on the changes proposed, nor did it reflect the opinions of high-ranking public functionaries; also, the bill was rejected both by the Senate and by the President. The whole process in which the new law was pushed through suggested, to quote President Klaus, that "the new law was motivated by interests, rather than material reasons." (Stanovisko prezidenta, 2011, p. 1). Moreover, the reform never won the hearts of civil servants at local labour offices as the key agents of its implementation. "I don't think there was resistance to reforms per se. Reforms are a part of life. The problem was that nothing was prepared, the whole thing was nontransparent, nobody knew which things would change and how, it was not on the discussion agenda." (FG2) From the very beginning, few believed in the meaning of the institutional reform. "Until the end of March 2011, nobody thought it would go live, so to speak. There was this uncertainty of whether they meant it seriously, whether they would actually do it. We didn't believe they would." (FG1)

\section{Implementation failure}

Nagel (2002) defines several types of obstacles to policy implementation that pertain, among other things, to technological, political, administrative, legal, economic and psychological feasibility. From its inception, the implementation of the 2011 institutional reform of employment services was faced with issues of political feasibility (absence of stakeholder consensus), administrative feasibility (unstable staffing of local labour offices along with the establishment of new regional offices) and psychological feasibility (absence of communication with client services and the fact that their staff doubted the reform's meaning). The human resources of local labour offices were scattered by three waves of layoffs, there were serious bugs in the single information system during the first couple of months of operation, and central management was unable to respond to the emerging problems. "Over the weekend we were making stamps and plates for the new authority. This is something the politicians didn't realize. I was amazed that the labour offices weren't shut down, after all" (Respondent 7) "They couldn't even imagine the ways the different agendas could be affected by the amendment of the Act on Employment. Paradoxically, it was up to us to 
feed information to the Ministry." (FG1) For example, in case the new information system was out of service and the labour office was unable to register an official approval of welfare benefits or an invitation to one the programmes of active employment policy, the ministry guided the staff of labour offices to use "pen and pencil" (and a calculator) (Nefunguje software, 2012). In many districts, welfare benefits were paid behind schedule, which led Minister Drábek to consider assuming political liability and resigning (Drábek věří, 2012).

The reform's implementation failure can also be attributed to systemic flaws in central management and guidance. Due to unclear division of centrallevel responsibilities between the Ministry and the General Directorate, the former continued to "be involved in everyday operations of the General Directorate much more frequently than before the reform... Instead of two managemen levels, we now have four." (Respondent 1) Moreover, due to a lack of coordination between the ways different ministry departments instructed their areas, "the regions have to coordinate and manage the different instructions on their territory, and as a result, we have 14 different systems. This is indeed no uniform environment." (Respondent 1 )

Management was not streamlined by the adding of a regional level because "everything takes longer and everything is now more complicated." (Respondent 1) Local labour offices are no longer responsible for allocating funds to active employment policy programmes and, as a result, they are less flexible in solving local labour market problems. "The concentration of responsibility in the hands of the region was simply ill-conceived. They realized there are literally tons of paperwork transported regularly to the regional offices." (FG2)

Finally, the information system was an important factor of the reform's implementation failure. It was designed to support employment brokering as well as uniform administration of welfare benefits by labour offices across the Czech Republic. "There was quite a big problem when the information systems were launched and the problem lasted for quite some time." ... "It was terribly sluggish and user-unfriendly." (FG2). In spite of the initial difficulties, the brokers and counsellors believe that "the idea of a centralized information system was not bad at all." (FG2)

\section{Negative impact of the institutional reform}

\section{on the functioning of labour offices}

The effects of the implemented organizational changes are perceived in a negative way, especially with regard to the quality of working conditions and human resources at labour offices. "The instability in human resources is the wors thing that happened. All kinds of damage were suffered by an immense number of people, I mean employees." (FG1) "Most colleagues were disgusted by the existing situation. Their salaries were reduced twice in a row and on top of that, they had to work extra hours. Some quit on their own for the above-mentioned reasons, and others (about two thousand people) were laid off. Eventually we were the only member state to reduce, rather than expand, the staffing of labour offices during the economic crisis." (Respondent 2)

Due to the significant understaffing of the different agendas, all operations were restricted to the very basics, i.e. payment of welfare benefits and assistance with emergencies (Zpráva o činnosti, 2014). There was an especially high frequency of emergencies following the launch of the new information system in January 2012. There were malfunctions in the information system and the staff did not obtain adequate training in operating it. "That was really sad for the people in the field, to take all the pressure from the outside and pretend everything was $\mathrm{OK}$ while another person was pushing them from behind. The software wasn't working. They didn't know what to do. They weren't allowed to tell something was wrong. They had to pretend that everything was working just fine." (FG1)

Furthermore, social work with people in material poverty, formerly done by municipalities, was strongly affected by the organizational reform of employment services. Labour offices' staff had to adapt to a type of activity that was completely new in the context of this office - not only providing social benefits to people in material poverty but also organizing social work. Musil et al. (2013) argue that it is practically impossible to make high-quality assistance by the office's social workers available to all clients, given the number of staff assigned to this agenda. As a result, the institutional changes might eventually pervert social work into pure administrative routine. "The only thing left is the paperwork machinery, while there is no more room for the essence of employment brokering or social work. ... In my opinion, employment counselling has been annihilated." (FG1) "The social benefit agenda is pulling the labour office under ... what we have is growing importance of the non-insurable social benefits agenda at the expense of the employment agenda - in terms of clientele, staffing, problems and funding." (Respondent 1)

\section{Damage to the reputation of public employment services}

As Bovens and t'Hart (1998) point out in their definition of policy fiascos, negative perceptions of the event at stake are associated with a variety of harms or losses. It is apparent that the institutional reform of public employment services in 2011 caused major political damage by undermining the reputation of labour offices as the main government body helping people who lost their job 
and cannot find another one. "I think it's going to take years for the reputation and professionalism to recover, if they recover at all. Personally, I don't believe they will." (FG2)

\section{POLICY FIASCO (4 ${ }^{\text {TH }}$ LAYER):}

\section{WAS THE POLICY FIASCO AVOIDABLE?}

As evidenced by the above-mentioned research studies and expert interviews, public employment services in the Czech Republic gradually ceased to fulfil their mission and some adjustments were needed (e.g., to streamline and unify management processes, to introduce innovative measures of active employment policy, to adapt to the specific needs of the long-term unemployed, to actively form cooperation with employers). The organizational changes of employment services of 2011 were targeted and implemented in problematic ways, thus undermining the operations of these services and causing a "big bang" (FG1). "The way everything worked until 2011 was just great, perfect amazing, compared to the present situation. 2011 was the critical year when it all got destroyed. It is going to be awfully hard to rebuild." (FG2) The government established arrangements that will be difficult to amend because there are not enough material and human resources to do so (Respondent 7) The policy fiasco, as we refer to the changes implemented, was avoidable, at least had there been enough time to prepare the changes, reconcile the comments submitted by political opponents and other government authorities (including ministries), and discuss the proposal in the Tripartite. Moreover, it would have been practical to implement the reform in a few stages with pauses between them to establish the new Labour Office first, to provide approximately two years for its internal processes to settle down, and then to transfer the welfare benefit agenda under its responsibility (Respondent 7).

\section{CONCLUSION}

The policy fiasco concept defined by Bovens and t'Hart (1998) and applied by them on a number of cases of important policy failures proved highly pertinent to the institutional changes of Czech public employment services in 2011 Guided by the interpretive paradigm, we conclude that the organisational changes to Czech employment services of the years 2011-2012 meet both main conditions indicating a policy fiasco. First, they are perceived by the stakeholders involved as events that caused substantial harm to the employment ser- vices. Second, the events were highly politicized, leading to resignation of the Minister of Labour and Social Affairs and criminal charges against a top manager of the Ministry. Our analysis of the reform of Czech employment services was guided by these two assumptions, as defined by Bovens and t'Hart (1998), and the fact that we were able to confirm them allows us to designate the events analysed as a policy fiasco. This approach respects the subjective views of stakeholders involved, who relate to the events based on their own values, beliefs and professional affiliations, and who necessarily emphasize different aspects of the operation of employment services. A policy fiasco scholar operates as an independent observer and seeks to reconstruct the stakeholders views in a broader context of the events at question (the mission of the employment services, their history, current trends etc.)

The institutional reform of employment services in the Czech Republic was ill-founded, non-consensual and ill-targeted. Its main goal was formulated inadequately: to achieve financial savings by changing the organisational structure of employment services and merging the welfare benefit agendas under the newly established Labour Office of the Czech Republic. Given the problems experienced by Czech employment services, we believe it would have been more adequate to formulate the reform's goal as improving and unifying the over-fragmented management and decision-making processes at all levels (central, regional and local). Such a goal would have been more acceptable to stakeholders and would have guaranteed more effective implementation. However, it could not be expected to result in financial savings, at least not in the short term. Moreover, Czech employment services require a more profound reform with regard to not only effective management but also their human resources, their portfolio of measures to promote employment, and their approach to clients. Apart from implementing modern and effective management forms, similar reforms in countries such as Germany, The Netherlands or Finland have sought to increase the involvement of stakeholders, including local governments, businesses and NGOs. Their ultimate goal has been to better respond to the individual needs of employment services clients - job seekers as well as employers (Výborná \& Kotrusová, 2015) When the organisational changes in Czech employment services of the years 2011-2012 are compared to the reforms abroad, it appears that stripping local governments of responsibility for addressing local labour market needs was a step in the wrong direction.

Under the pressure of political leadership, the preparation of the institutional reform as well as the implementation process were unusually swift. The time pressure resulted in a series of management failures, in a failure to prepare related laws while responding to emerging problems affecting the operations of the new Labour Office. Since the General Directorate and regional 
offices of the Labour Office took a long time to get established, they were unable, at least initially, to effectively discharge their management roles vis-à-vis local labour offices. Amidst the ensuing chaos, the main burden of implementing the organizational changes was carried by street-level bureaucrats who were themselves facing increased job insecurity and a substantial deterioration of working conditions.

The policy fiasco that clearly affected the operation of Czech public employment services in 2011 led most key stakeholders to believe that the political leaders were motivated by their own covert goals. This belief was strengthened by the ongoing criminal prosecution for bid rigging with respect to the new information system. According to our respondents, the goals were to transfer a segment of better-employable clients to private service provid ers, to undermine the implementation of active employment policy by labour offices, and to reduce the role of labour offices to payment of welfare benefits. Even prior to the reform, the Labour Office had been considered primarily as a place to collect unemployment benefits. Without a major shift of emphasis from effective ways of disbursing welfare benefits to real solutions of unemployment problems, this perception of the way Czech employment services operate can only be expected to prevail.

\section{REFERENCES}

Araral, E., Fritzen, S., Howlett, M., Ramesh, M., \& Wu, X. (2012). Routledge handbook of public policy. New York, NY: Routledge.

Barbour, R. (2008). Doing focus groups. London: Sage.

Birkland, T. A. (2005). An introduction to the policy process: Theories, concepts, and models of public policy making. Rome, Italy: Gremese Editore.

Boeri, T. \& Burda, M. C. (1996). Active labor market policies, job matching and the Czech miracle. European Economic Review, 40(3), pp. 805-817.

Bogner, A., Littig, B. \& Menz, W. (Eds.). (2009). Interviewing experts. Basingstoke: Palgrave Macmillan.

Bovens, M. \& t'Hart, P. (1998). Understanding policy fiascoes. New Brunswick: Transaction Publishers.

Boyatzis, R. E. (1998). Transforming qualitative information: Thematic analysis and code development. Sage Publications.

Braun, V. \& Clarke, V. (2006). Using thematic analysis in psychology. Qualitative Research in Psychology, 3 (2). pp. 77-101.

Castles, S. (2004). Why migration policies fail. Ethnic and racial studies, 27(2), pp. 205-227.

Colebatch, H. K., Hoppe, R. \& Noordegraaf, M. (Eds.). (2010). Working for policy. Amsterdam: Amsterdam University Press.

De Mesquita, B. B., Morrow, J. D., Siverson, R. M. \& Smith, A. (1999). Policy Failure and Political Survival The Contribution of Political Institutions. Journal of Conflict Resolution, 43(2), pp. 147-161.
Drábek věři, že nebude muset opustit vládu kvơli výplatě dávek. [Drabek believes he will not have to leave the government for payment of benefits.] Retrieved February 14, 2012, from http://zpravy.idnes.cz/drabek-odstoupi-kdyz-do-brezna-zustanouproblemy-na-uradech-prace-1c4-/domaci.aspx?c=A120214_150545_domaci_jj

Evans, T. (2010). Professional Discretion in Welfare Services: Beyond Street-Level Bureaucracy. England, USA: Ashgate Publishing Group.

Dosavadní návrhy na zlepšeni služeb zaměstnanosti. (2007). [Proposals to the improvement of the public employment services.] Institut trhu práce, Praha: Národní vzdělávaci fond.

Fiala, P. \& Schubert, K. (2000). Moderní analýza politiky. [Modern policy analysis.] Praha: Barrister \& Principal.

Flick, U. (2014). An introduction to qualitative research. Sage.

Gitter, R. J. \& Schever, M. (1998). Low unemployment in the Czech Republic: miracle or mirage. Monthly Lab. Rev., 121, pp. 31-37.

Hoppe, R. (1999). Policy analysis, science and politics: from 'speaking truth to power' to 'making sense together'. Science and public policy, 26(3), pp. 201-210.

Hoppe, R. (2011). The governance of problems: Puzzling, powering and participation. Bristol, UK: Policy Press.

Howlett, M. \& Ramesh, M. \& Perl, A. (2009). Studying Public Policy: Policy Cycles and Policy Subsystems. Oxford University Press.

Howlett, M. (2012). The lessons of failure: learning and blame avoidance in public policymaking. International Political Science Review, 0192512112453603.

Ingram, H. M. \& Mann, D. E. (1980). Why policies succeed or fail. Berkeley: Sage Publications.

Integrovaný portál MPSV: Úřad práce České republiky. [MoLSA integrated portal: Labour Office of the Czech Republic.] Retrieved February 10, 2014, from http://portal.mpsv.cz/ upcr/oup

Kalužná, D. (2008). Main Features of the Public Employment Service in the Czech Republic (No. 74). Paris: OECD Publishing.

King, N. \& Horrocks, C. (2010). Interviews in qualitative research. Sage.

Kitzinger, J. (1995). Qualitative research: Introducing focus groups. British Medical Journal, 29(July), 299-302. Retrieved August 10, 2007, from http://www.bmj.com/cgi/content/ full/311/7000/299

Kotíková, J. et al. (2000). Úloha politiky zaměstnanosti v oblasti pracovně profesního poradenstvi při zprostředkování zaměstnání. [The role of employment policy in professional counselling and job brokerage.] Praha: VÚPSV.

Kotrusová, M. \& Výborná, K. (2014). Zhodnocení institucionální reformy veřejných služeb zaměstnanosti v roce 2011 v Ceské republice. [Evaluation of the public employment services reform in 2011 in the Czech Republic.] Fórum sociální politiky, (6), pp. 10-17. McConnell, A. (2010) Understanding Policy Success: Rethinking Public Policy. UK: Palgrave. McConnell, A. (2013) Learning from success and failure in Araral, E., Fritzen, S. \& Howlett, M. (Eds.). (2012). Routledge Handbook of Public Policy. New York, NY: Routledge.

MoLSA (undat.) Nová organizace služeb zaměstnanosti (návrh zákona o Úřadu práce ČR). [New employment service organisation, bill on the Labour Office of the CR.] 
Musil, L., Hubíková, O., Havlíková, J., \& Kubalčíková, K. (2013). Raná fáze implementace reformy $v$ rámci agendy dávek pomoci $v$ hmotné nouzi. [Early implementantion of social benefits reform.] Praha: VÚPSV.

Nohl, R., Novák, J. \& Šídlová, T. (2012) Ministr Drábek odstoupil. Přebirám odpovědnost rekl. [Minister Drabek resigned. I take responsibility, he said.] Retrieved October 03, 2012, from http://zpravy.aktualne.cz/domaci/politika/ministr-drabek-odstoupilprebiram-odpovednost-rekl/r i:article:759248/

Nagel, S. S. (Eds.). (2002). Handbook of public policy evaluation. Sage.

Návrh poslanců Martina Vacka, Jitky Chalánkové, Miroslava Jeníka a dalších na vydán zákona o Úřadu práce České republiky a o změnách souvisejících zákonů. (2010) [MP's Bill on the Labour Office of the Czech Republic and changes of the other bills.] Parlament České republiky, Poslanecká sněmovna.

Nefunguje software? Použijte tužku a papír, radí úradu práce ministr Drábek. [Software does not work? Use the stylus and paper advises Labour Office Minister Drabek.] Retrieved February 18, 2012, from http://www.parlamentnilisty.cz/arena/monitor/ Nefunguje-software-Pouzije-tuzku-a-papir-radi-uradu-prace-Drabek-223371

OECD. (2009). Flexible Policy for more and better jobs. Managing accountability and flexibility. Paris: OECD Publications Service.

Orenstein, M. (1994). The political success of neo-liberalism in the Czech Republic. CERGE-EI Working Paper Series, (68).

Práce a sociální politika. [Labour and Social Policy], Volumes 2011-2012, http://www.mpsv. $\mathrm{cz/cs/3645.}$

Programové prohlášení vlády České republiky. [Policy statement of the Government of the Czech Republic] 4. 8. 2010. Retrieved January 08, 2014, from http://www.vlada.cz/ assets/media-centrum/dulezite-dokumenty/Programove_prohlaseni_vlady.pdf

Reichel, J. (2009). Kapitoly metodologie sociálních výzkumů. [Chapters in social sciences methodology.] Praha: Grada Publishing a. s.

Sirovátka, T., Kofroňová, O., Kotíková, J. \& Winkler, J. (2003). Problémy trhu práce a politiky zaměstnanosti. [Labour market and employment policy problems.] Praha a Brno: NVF, MU Brno.

Sirovátka, T. (2008). Activation policies under conditions of weak governance: Czech and Slovak cases compared. Central European Journal of Public Policy, (1), pp. 4-29.

Sirovátka, T. \& Winkler, J. Governance of Activation Policies in the Czech Republic:

Uncoordinated Transformation. in van Berkel, R., de Graaf, W. \& Sirovátka, T. (2011) The Governance of Active Welfare States in Europe (pp. 173-194). England: Palgrave Macmillan.

Slovo ministra. [Word of Minister.] Práce a sociální politika Retrieved February 09, 2011, from http://www.mpsv.cz/files/clanky/10330/Prace_socpol_02_11_web.pdf

Slovo ministra, [Word of Minister.] Práce a sociálni politika. Retrieved February 12, 2011 from http://www.mpsv.cz/files/clanky/10162/Prace_socpol_01_11_web.pdf

Stanovisko prezidenta republiky. (2011). [Opinion of the President of the CR.] Parlament České republiky, Poslanecká sněmovna.

Veselý, A. \& Nekola, M. (Eds.). (2007). Analýza a tvorba veřejných politik: př́stupy, metody a praxe. [Analysis and creation in public policy: approaches, methods and practice.] Praha: Sociologické nakladatelství Slon.
Vláda České republiky. Vláda doporučila ukončení projektu S-karty. [Government recommended the termination of the project S-Card.] Retrieved May 02, 2013, from http://www.vlada.cz/cz/media-centrum/aktualne/vlada-doporucila-ukonceni-projektuskarty-106263/

Vlková, J. \& Petrášová, L. (2013). Ministerstvo práce podalo čtyří trestní oznámení, miríi na Drábka a Šišku. [MoLSA filed four criminal charges, pointing at Drabek and Šiška.] Retrieved November 23, 2013, from http://zpravy.idnes.cz/konicek-podal-trestnioznameni-kvuli-cinnosti-drabka-a-sisky-ptd-/domaci.aspx?c=A131123_073420_ domaci_hv

Výborná, K. \& Kotrusová, M. (2015). Reformy veřejných služeb zaměstnanosti ve vybraných evropských zemích. [Reform of public employment services in selected European countries.] Fórum sociální politiky, (1), pp. 23-26.

Vylítová, M. et al. (2000). Optimalizace organizační struktury a ř́dicich funkcí služeb zaměstnanosti. [Optimization of organizational structure and executive functions of employment services.] Praha: VÚPSV.

Weimer, D. L. \& Vining, A. R. (2005). Policy analysis: Concepts and practice. Oxford University Press.

Yanow, D. (2006). Qualitative-Interpretive Methods in Policy Research. in: Fischer, F. Miller G.J. \& Sidney, M.S. Handbook of Public Policy Analysis (pp. 405-416). Taylor \& Francis Group: CRS Press.

Zpráva o činnosti Úřadu práce České republiky za rok 2013. (2014). [Report on the activities of the Labour Office of the Czech Republic for the year 2013.] Praha: Generální reditelství Úřadu práce ČR. 